\title{
LUBLÓY Ágnes
}

\section{MAGYARORSZÁGI BANKFÚZIÓK ÉS A BANKSZEKTOR JÖVÖJE}

A szerző tanulmányában a magyarországi bankfúziókkal, a bankfúziók okával és a várható jövőbeli bankpiaci folyamatok elemzésével foglalkozik. E folyamatok nyomán kialakult versenyhelyzetnek igazi nyertesei a banki ügyfelek lehetnek, hisz mindinkább hasonló infrastruktúrájú bankok versengenek a kegyeikért. A méretstruktúra kiegyenlítettebbé válásához minden bizonnyal a jelenlévő piaci szereplők fúziói és felvásárlásai is hozzájárulnak. A szerző egyfajta vízióként egy kettős struktúrájú magyar bankszektort valószínúsít, ahol mintegy tíz nagybank mellett számos, szúk piaci szegmensre szakosodott pénzügyi intézmény lesz majd megtalálható.

A 90-es években a nyugati-európai bankrendszerekben fúziós és felvásárlási hullám indult el. Ez a magyarországi bankpiacot kétféleképpen érintette. Egyrészt a külföldi fúziók hazai lecsapódásakor a magyarországi leányvállalatok is összeolvadtak. Itt legjobb példaként a Bank Austria Creditanstalt Hungary és a Hypo Vereinsbank Hungaria 2001-ben realizálódó fúzióját említhetjük, ami tulajdonképpen a két anyabank fúziójának a következménye. A 2000-es év mérlegfőösszege alapján a 14. helyen lévő Hypo Vereinsbank és a 11. helyen lévő Bank Austria Creditanstalt összeolvadása révén közel 540 milliárd forint mérlegfőöszszeggel az új HVB Bank 2001-ben már az ötödik helyet foglalja el a bankrangsorban (Bankok és szakosított..., 2000; 2001). 2003 végére a fuzionált bankok mérlegfőösszege 734 milliárd forintra nőtt, ami a mérlegfőösszeg alapján számított bankrangsorban a hatodik helyet jelentette (Bankok, rekorderek..., 2004). A másik oldalról ugyanakkor a nyugat-európai fúziós hullám hatására az erőforrások és a befektetések jelentős része az Európai Unió piacára terelődött vissza, aminek következtében a felvásárló bank a felvásárolt bank tulajdonában lévő magyarországi bank eladásáról döntött. Így került sor például 1997-ben az Európai Kereskedelmi Bank Citibanknak történő eladására, amikor is az EKB fő tulajdonosa, a Bank Austria a Creditanstalt tulajdonosává vált (B.Varga, 2001a).
A magyarországi bankfúziók egyik speciális esetét jelenti az, amikor a profitrés szúkülésével a bankok fúzió révén igyekeznek hatékonyabbak lenni. Hatékonyságnövekedési célok vezérelték a Kereskedelmi és Hitelbank Rt. és az ABN Amro Magyar Bank Rt. fúzióját. ${ }^{1}$ Az ABN Amro Bank magyarországi leányvállalatának a múltból öröklött problémákkal - kétes kihelyezések után képzett tartalékok, hatékonysági problémák - kellett szembenéznie, ami jelentős pénzösszegeket emésztett fel. Emellett a banknak meglehetősen költséges informatikai, infrastrukturális - fejlesztéseket is meg kellett megvalósítania. A mérlegfőösszeg nagysága szerinti negyedik és ötödik helyen szereplő $\mathrm{K} \& \mathrm{H}$ és az ABN Amro 2001-ben fuzionáltak, aminek következtében 1100 milliárd forintot meghaladó mérlegfőösszegével, 220 fiókkal, 650 ezer lakossági és 60 ezer vállalati ügyféllel Magyarország második legnagyobb bankjává váltak. A vállalati üzletágban a fúzió a piacvezető pozíció megszerzését jelentette, míg a lakossági piacon a második helyet (Ahogy a Moody's..., 2000). A két bank fúziója azért különösen érdekes, mert a belga KBC Bank többségi tulajdonában lévő Kereskedelmi és Hitelbank, valamint a holland többségi tulajdonban lévő ABN Amro Bank úgy fuzionáltak, hogy az anyabankok megőrizték önállóságukat.

Szintén hatékonyságnövekedési célok vezérelték a lakás-takarékpénztárak piacán végbemenő folyamato- 
kat. 2002. szeptember 1-jén a Lakáskassza átvette az Otthon Lakás-takarékpénztár Rt. szerződés- és ügyfélállományát, és ezzel a hazai lakás-takarékpénztári piac 30 százalékát tudhatta magáénak mind a szerződések darabszámát, mind értékét tekintve. Ezt követően 2003. július 1-jével a Fundamenta Rt. és a Lakáskàssza-Wüstenrot Rt. fúziójával megalakult a Fundamenta-Lakáskassza Rt. Ahogy a Fundamenta-Lakáskassza Lakás-takarékpénztár Rt. küldetéséből kiderül, a fúzió legfontosabb célja a két nemzetközi háttérrel rendelkező pénztár még erőteljesebb részt vállalása a magyarországi piaci tendenciák alakításában, valamint az ügyfélközpontúság további fejlesztése. Méretéből adódóan az új lakás-takarékpénztár jobban tudja majd ügyfelei érdekeit képviselni. A gazdaságos méretből és költségmegtakarításból származó többletet pedig az ügyfelek számára fontos területek további fejlesztésére lehet költeni (A Fundamenta-Lakáskassza..., 2004).

A magyarországi bankfúziók jelentős része az állami privatizáció következtében valósult meg. A Merkantil Bank 1996-os privatizációjakor az OTP Bank Rt. 100\%-os tulajdonába került. A Merkantil Bank kezdetben az Országos Kereskedelmi és Hitelbank leánybankjaként váltóleszámítolással, faktoringgal és lízinggel foglalkozott, azóta fő tevékenysége a gépjármủ-finanszírozás, a vállalkozások eszközbeszerzéséhez nyújtott pénzügyi segítség és az ingatlanfinanszírozás (Merkantil Bank, 2004). A volt állami tulajdonú bank mára egy jól körülhatárolt réspiacra szakosodott bank lett. A Postabank jövője 2003 októberében dőlt el, amikor az Állami Privatizációs és Vagyonkezelő Részvénytársaság az Erste Bankot nevezte meg a Postabank és Takarékpénztár Rt. privatizációjára kiírt tender győzteseként. Az Erste Bank 101,3 milliárd forintot, közel 400 millió eurót ajánlott a részvények 99,97 százalékáért. 2003 végén a közel 1000 milliárd forintos mérlegfőösszegű új Erste Bank az ötödik legnagyobb magyar bankká avanzsált elő, a lakossági piacon a tranzakciót követően pedig a második legnagyobb bank lett (Zöld utat..., 2003). Az 1987-ben alapított, 1995 óta a Magyar Fejlesztési Bank csoporthoz tartozó kis- és középvállalkozások finanszírozásban aktív Konzumbankot a Magyar Külkereskedelmi Bank szerezte meg. Az MKB az ÁPV Rt. nyilvános egyfordulós pályázatának keretében 10,8 milliárd forintért vásárolta meg a Konzumbank Rt. 99,6\%-os tulajdoni hányadát megtestesítő részvénycsomagot és az általa székházként használt ingatlant (MKB, Bemutatkozunk..., 2004). Ahogy a Merkantil Bank, a Postabank és a Konzumbank esete is mutatja, a bank- privatizáció utolsó fázisában új piaci szereplő belépése nem volt prognosztizálható, jó esély volt arra, hogy a privatizációra kiírt bankokat egy már jelenlévő szereplő vásárolja meg és integrálja saját szervezetébe.

\section{A bankfúziók oka}

A bankfúziókat vizsgálva általánosságban elmondható, hogy a koncentrációs folyamat különbözik a gazdaság többi szegmensének koncentrációs folyamatától. A bankszektorban a fúzió elsődlegesen nemzeti keretek között történik, a növekedés leginkább a banki és pénzügyi szolgáltató szféra nemzeti szereplőinek összeolvadását, országokon belüli koncentrációját eredményezi (Tompa et al., 2001).

A fúziók főként a piaci verseny erősödésére vezethetők vissza. A piaci verseny fokozódása kikényszeríti a méret- és tevékenységgazdaságosság (economies of scale and scope) biztosította előnyök kiaknázását. Méretgazdaságosságnak nevezzük a nagybani termeléssel járó előnyöket, azokat a megtakarításokat, amelyek a ráfordítások mennyiségének növelésével érhetők el. A rövid, illetve hosszú távú átlagos és határköltség-függvények alapján a méretgazdaságosság azt jelenti, hogy egy termék termelésének átlagköltsége hosszú távon ceteris paribus csökken, ahogy a kibocsátás nő. Azaz méretgazdaságosság vagy növekvő hozadék akkor jelentkezik, ha az összes input x százalékkal történő növelésével egyidejűleg az output több mint x százalékkal növelhető (Kopányi, 1999). A méretgazdaságosság előnyei azonban csak a termelés bizonyos nagyságrendjéig érezhetők. A szervezetek növekedésének bizonyos szintje után a méretgazdaságtalanság (diseconomy of scale) kezd érvényesülni, a szervezet veszít hatékonyságából, a működtetés drágul, nő az átlagköltség. A méretgazdaságosságon belül megkülönböztethetjük a belső, illetve a külső méretgazdaságosságot. Belső méretgazdaságosságról akkor beszélünk, amikor a vállalat maga növekszik, míg a külső méretgazdaságosság az adott iparág növekedését jelenti (Economies of scale..., 2002). A bankrendszer vizsgálata esetében igazából az előbbinek van értelme, hisz az utóbbi elméletileg ugyanúgy érinti az összes szereplőt. Az már egy másik kérdés, hogy melyik piaci szereplő mekkora hányadot tud a növekedés révén létrejött új piacból megszerezni.

Tevékenységgazdaságosságnak nevezzük a több terméktípus együttes termeléséből származó előnyöket, azokat a megtakarításokat, amelyek a termékpa- 
letta bővítésével érhetők el. A tevékenységgazdaságosság tehát azt jelenti, hogy megtakarítás érhető el abban ez esetben, ha egy vállalat egyszerre több terméket termel, vagy szolgáltatást nyújt, ahhoz az esethez képest, ha ezen tevékenységet több különálló szervezetben fejtenék ki.

A méret- és tevékenységgazdaságosságnak a bankok esetében számtalan forrása lehet (Mouyneux Altunbas - Gardener, 1997). Egyrészt egy magasabb kibocsátási szint realizálása nem feltétlenül jelenti az állóeszköz-állományok, illetve a folyó költségek arányos növekedését, azaz a nagyobb mérettel járó nagyobb termelési volumen mellett az egységnyi termékre jutó fix költségek jobban szétteríthetők, az átlagos költségek csökkennek. Másrészt a nagyobb méret az erőforrások megosztását és így hatékonyabb felhasználását teszi lehetővé. Kisbankok esetében a specializáció nem igazán lehetséges, egy alkalmazottnak számos, olykor igen eltérő feladatot kell ellátnia. Nagybankok esetében ugyanakkor a munkamegosztás jól megvalósítható, aminek következtében emelkedik a termelékenység. Fúzió esetén az erőforrások megosztása a racionalizálásban, az átfedések megszüntetésében és bizonyos eszközök közös használatában ölt testet. Harmadrészt bizonyos költséges innovációk bevezetése, működési, fejlesztési know-how átvétele például egy új számítógépes szoftver - a nagybankoknál gazdaságosabb. Negyedrészt a nagybankoknak kisebb arányban kell készpénzt tartaniuk, mint a kisbankoknak. A pénztartás költsége miatt a nagybankok így költségmegtakarítást érhetnek el. Ötödrészt megtakarítás érhető el amiatt is, hogy a nagybankok esetében gyakorlatilag ugyanaz a menedzseri és adminisztrációs személyzet sokszor elégségesnek bizonyul a megnövekedett feladatmennyiségek ellátására, azaz a menedzseri és az adminisztrációs feladatokat ellátó alkalmazottak száma relatíve alacsonyabb. Fúzió esetén egy másik vállalattól átvett új vezetési, irányítási módszerek következtében javulhat a cég teljesítménye és eredményessége, köszönhetően a szervezeti kultúrában, a vezetési stílusban, a munkacsoport hatékonyságában és a munkatársak motiváltságában bekövetkezett változásoknak. Hatodrészt jobban megoszlanak a beszerzési és a marketingköltségek. Hetedrészt több tekintetben is költségmegtakarítás érhető el ott, ahol egy szervezeten belül számos terméket gyártanak, illetve szolgáltatást nyújtanak: ez

- ugyanis lehetőséget biztosít az árukapcsolásra, illetve arra, hogy a különböző részlegek egyaránt használják ugyanazt az információt. Az árukapcsolás egyúttal jelenti a fix költségek jobb terítését, a kockázat mérséklését, illetve a vevő tranzakciós költségeinek csökkenését. Végül egy nagybank a kliensek szemében biztonságosabbnak tűnhet, ez a tény már magában is több ügyfelet garantál.

A méret- és tevékenységgazdaságosság nyújtotta fenti előnyök mellett a fúzió magyarázatához tartozik az is, hogy így lehetőség nyílik új piacok megszerzésére. Ez jelentősen megnövelheti a bank piaci erejét, illetve hozzáhárulhat a versenytársakkal való sikeresebb rivalizáláshoz. Másrészt a bank tökéletesítheti addigi termékportfólióját is.

A piaci verseny fokozódása a bankokat a forgalom növelésére és a nagyobb üzemméret, a tevékenységgazdaságosság nyújtotta előnyök kihasználására és így felvásárlásra és összeolvadásra készteti, kényszeríti. E stratégiai döntés következtében ugyanis nő a bank piaci részesedése, szélesedik a tevékenységi köre, a végrehajtott racionalizálás következtében csökkennek a költségei, illetve adott esetben adómegtakarítása keletkezik, valamint fokozódik a növekedési üteme, azaz az élesedő versenyben egyre inkább képes megállni a helyét. Felmerülhet a kérdés, hogy vajon a piaci verseny fokozódása készteti-e a bankokat a méret- és tevékenységgazdaságosság nyújtotta előnyök kihasználására, és így a fúzióra, avagy a méret- és a tevékenységgazdaságosság kihasználásának célja váltja ki az összeolvadást, ami pedig erősíti a piaci versenyt. Véleményem szerint az előbbi a helyzet, önmagában a méret- és tevékenységgazdaságossági cél nem váltaná ki az összeolvadást, felvásárlást. Kell egy külső kényszer, hatás is. Ráadásul az összeolvadás nem erősíti, hanem gyengíti a versenyt, hisz csökken a piaci szereplők száma. Eltekintve természetesen az olyan paradox helyzettől, mint ami Magyarországon fennáll. Hazánkban ugyanis az összeolvadás kiegyenlítettebbé teszi a struktúrát, ami erősíti a versenyt, és így újabb összeolvadásra késztet.

A bankszférában kialakult fúziós hullám a méret- és tevékenységgazdaságossági magyarázat mellett még számos más okra is visszavezethető. Egyrészt az országok közötti és a vállalati szinten jellemző integrációs törekvések ösztönzik a bankfúziót. A létrejött nagy piacok ugyanis - EU, NAFTA - még tovább erősítik a már amúgy is ádáz versenyt, és ezáltal kikényszerítik a méret növelését. Másrészt a verseny fokozódása, a bankok közti rivalizálás a nagy ügyfélkörrel és hálózattal rendelkező, széles tevékenységű bankok helyzetét szilárdítja meg, ami a kisebb bankokat és pénz- 
intézeteket fúzióra vagy összeolvadásra készteti, főként, hogy a verseny a nem banki pénzügyi szolgáltatók - biztosító társaságok, nyugdíjalapok, különféle pénzügyi vállalkozások - között is erősödik. ${ }^{2}$ Harmadrészt gazdasági recesszióban összességében is több banki fúzióra számíthatunk, mivel több kisebb bank csődközeli helyzetbe kerülhet. A sorozatos bankcsődök elkerülése érdekében a kormány legtöbbször konszolidációt hajt végre, majd a kisbankokat fúzióra ösztönzi, hisz a méret bizonyos garanciákat nyújthat biztonságos működésükhöz. Negyedrészt az egyre gyorsuló technológiai változások és belső banki tényezők a nagyobb méretre és több tevékenységre kiterjedő egységes technikai rendszerek kialakítását ösztönzik, ami csökkenti a fajlagos költségeket. Külső hatásként pedig az egyedül túl nagy kockázatot jelentő hiteligény, a dezintermediációs folyamat és a gyorsabb, korszerűbb kiszolgálási színvonal követelménye kényszeríti ki a bankok méretének növelését (Tompa et al., 2001). A fúziós hullám eredményeképp az Európai Unióban a hitelintézetek száma az 1994-es 9938-ról 1999-re 8330-ra, azaz közel 20\%-kal csökkent. A legjelentősebb csökkenéssel Portugália $(-27,5 \%)$, Belgium $(-27 \%)$, Spanyolország $(-24,1 \%)$, valamint Franciaország és Németország (mindkettő -18,2\%) szembesült (Special Features..., 2001).

\section{Valószínűsíthető jövőbeli hazai folyamatok}

A magyar bankrendszer struktúrája a közép- és kelet-európai országok bankrendszeréhez képes is elaprózódott. Meglehetősen kevés a nemzetközi versenyben és a piac teljes kiszolgálásában egyaránt hatékony bank. A hazai bankok nagy része sem méretében, sem tevékenységi körében nem elégíti ki az univerzalitás elvén szervezett, több funkciójú, banki, befektetési és biztosítási területen egyaránt tevékenykedő versenyképes méretű bankok kritériumait. Az OTP-t például számos lengyel és cseh pénzintézet megelőzi, a 25 legnagyobb közép- és kelet-európai bank közül csak négy magyar $^{3}$ (Novák - Wisniewski, 1999). Ugyanakkor a nemzetközi trendek alapján, az Európai Unióba való csatlakozásunkat követően elengedhetetlen az alkalmazkodás, a versenyképesebb struktúra biztosítása. Az EU-konformitás mindenképpen a nemzetközi szempontból is tőkeerős, nagy forgalmú pénzügyi intézmények létrejöttét indokolja, olykor a fajlagos jövedelmezőség mértékétől függetlenül.

Magyarországon az Európai Unió teljes jogú taggá válását követően több mint 50 , eddig még jelen nem lévő szereplő nyújt határon átnyúló szolgáltatást (Piaci szereplők..., 2004). A csatlakozás pillanatától ugyanis bármely uniós tagállamban bejegyzett hitelintézet szabadon alapíthat fiókot, illetve nyújthat határon átnyúló szolgáltatást, mégpedig az eddigi előírt külön tőkekövetelmény, a dotációs tőke nélkül. A fióktelep kockázatvállalását pedig nem a fiók, hanem az anyabank tőkeereje határozza meg. A fióktelepek tömeges megjelenését azonban nem tartom valószínűnek. Egyrészt, aki jelen szeretne lenni, az már eddig is jelen volt a piacon, másrészt a verseny már így is elég erős, ami a profitmarzsok általános szükülésével jár. Harmadrészt pedig egy-egy bankfiók nyitása nem elégséges a kis- és középvállalatok és a lakosság által igényelt, személyes kapcsolatot feltételező masszív piaci jelenléthez. Ahhoz ugyanis egy egész fiókhálózatra, a helyi viszonyok alapos ismeretére van szükség, egy adott ügyfélkör megszerzése pedig meglehetősen költséges, főleg amikor több bank is már erősebb versenyhelyzettel szembesült, mint amit korábban feltételezett, a terjeszkedés költségesebbnek és időigényesebbnek bizonyult a korábbi várakozásoknál. Ennek eminens példája a korábban külön említett $\mathrm{ABN}$ Amro Bank esete. Ha lesznek is új belépők, ahogy 2004-ben az ELLA Első Lakáshitel Kereskedelmi Bank Rt., 2003-ban pedig a Sopron Bank, illetve a Bank of China volt, az érdemben nem befolyásolja a piacot. ${ }^{4}$ Az új piaci szereplők ugyanis általában szűk piaci résre szakosodnak.

Magyarországon további fúziók nemcsak azért valószínűsíthetők, ${ }^{5}$ mert a bankok versenyképességét tekintve az ,alulbankosodás” jellemző, tehát hiányoznak a nemzetközi összehasonlításban ütőképes bankok, hanem azért is, mert a bankok számát tekintve a „túlbankosodás” figyelhetô $\operatorname{meg}^{6}$ (Tompa et al., 2001: 7. o.). A hazai bankok gyenge költséghatékonysága nagymértékben az alacsony ügyfélszámból ered, ami egy erősödő versenyben komoly versenyhátrányt jelent. Láthattuk, hogy fúziókra a múltban is bőven volt példa, és várhatóan a jövőben is lesznek fuzionáló bankok. A kereskedelmi bankok körében a jövőbeni fúziókat több csoportra bontanám. A fúziók egyik csoportja a nemzetközi tendenciák begyürüzéséhez kapcsolható. A magyarországi bankokat működtető külföldi bankok egyesüléseivel egyesülnek a hazai leányvállalatok is. A fúziók másik csoportjába azokat az eseteket sorolnám, amikor egy külföldi tulajdonban lévő hazai bank egy másik - valószínűsíthetően szintén külföldi tulajdonban lévő - magyarországi bankkal egyesül, mégpedig úgy, hogy az anyabankok nem 
fuzionálnak. E fúziós törekvéseket korlátozza azonban az a tény, hogy a hazai bankok többségének jó nevű külföldi tulajdonosa van, akik ahelyett, hogy elismernék a magyarországi vereségüket, és fúzió révén igyekeznének a tőkekövetelményeknek megfelelni, valamint a hatékonysági problémákkal szembenézni, inkább tőkejuttatás keretében tovább finanszírozzák leányvállalataikat. Azonban csak idő kérdése, hogy mikor mondanak nemet a további finanszírozásra, és igent egy fúzióra. Így tette ezt a korábban szintén önálló hídfőállás kiépítésén fáradozó $\mathrm{ABN}$ Amro, elismerve, hogy alulmaradt elsősorban a lakossági szektorért folytatott versenyben. Kudarcait maga mögött hagyva visszavonult. $\mathrm{Az} A \mathrm{ABN}$ Amro esete azonban nem számít kivételnek. A 90-es évek elején belépő új külföldi bankok meglehetősen nagy versenyelőnyt élveztek, ami elkényelmesítette őket. Nem volt céljuk a kevésbé jövedelmező lakossági szektor felé nyitni, amikor azonban a verseny erősödése kikényszerítette ezt, addigra már késő volt. Az OTP résen volt, és sikeres piaci és fejlesztési stratégiája révén megőrizte első helyét a lakossági piacon, és ügyfeleket szerzett a vállalati szférában is.

Az utóbbi években a bankszektoron belül $a$ szük piaci résre szakosodott bankok súlya dinamikusan növekedett. Ez tulajdonképpen egy olyan másodvonalbeli csoport, amelyek tevékenysége a gazdaságban nélkülözhetetlen. Szűk piaci résre szakosodva alapvető fontosságú feladatot látnak el, ugyanakkor kérdéses, hogy nem lehetne-e azt - jogi formájukat akár megtartva - egy pénzügyi konglomerátumba integrálódva hatékonyabban és költségtakarékosabban ellátni. Véleményem szerint igen. Élő példaként az OTP csoport 100\%-os tulajdonában lévő Merkantil Bankot, a BNP 75\%-os tulajdonában lévő Magyar Cetelemet vagy a HVB Jelzálogbankot említhetnénk. A szereplők másik körénél ilyen egyértelmű hozzárendelés nem figyelhető meg. Kérdéses, hogy a „stratégiai partnerrel” nem rendelkező szereplők köre kit és mikor talál meg magának, ha egyáltalán megtalál.

A bankszektor további koncentrációjához a fúziók mellett bizonyos szereplők kivonulása is hozzájárul. A szereplők többsége a piacról nem távozik, hanem egy szűk tevékenységi körre szakosodik. Ahogy tette ezt például a Nomura, a Kvantum Investment Bank, a Rabobank vagy a Societé Générale. ${ }^{7}$ Persze az sem kizárt, hogy idővel ezen intézmények is valamely nagybankba olvadnak be. A fúziós hullám ugyanis nemcsak a bankok között jelentkezik, hanem a pénzügyi szektor más szereplőinek vonatkozásában is. Úgy tűnik a két, egymással elvileg ellentétes nézet - az univerzális, illetve a funkcionális - közül az első, az univerzalitás elvén felépülő bankok arattak diadalt. Számos fúzió a különböző típusú pénzügyi szolgáltatásokat is végző, korábban nem is feltétlenül banki funkciókhoz sorolt pénzügyi intézmények összeolvadását jelenti, ezt a jelenséget „allfinance”-nak nevezzük. Teljes körű pénzügyi szolgáltatást végző pénzügyi konglomerátumok jönnek létre, mint például az ING, amelyek mindhárom pénzügyi területen - a banki, a biztosítási és a befektetési - integrált fiókhálózattal, integrált szolgáltatásokkal, egy adott ügyfélkörre integrált piacon tevékenykêdnek. Ez pedig költséghatékonyabb, méret-' és tevékenységgazdaságosabb, azaz versenyképesebb működést jelent. ${ }^{8}$

\section{Egy lehetséges jövőbeli helyzetkép}

Országhatárainkon túl tekintve, a kisebb európai országokat figyelembe véve a magyar bankszektor koncentrációjának mértéke nem számít magasnak. Az OTP-nek, amely mérlegfőösszege 2003 végén 2,4szerese az ôt követô Kereskedelmi és Hitelbanknak, a piaci részesedése $20 \%$ körüli. A három legnagyobb bank együttes piaci részesedése $40 \%$ körüli, a négy legnagyobb bank a bankrendszer eszközállományának 47\%-át tudhatja magáénak (Bankok, Rekorderek..., 2004). Összehasonlításképp, 2002 végén Belgiumban például 65 bankból a négy legnagyobb bank a bankrendszer eszközállományának $85 \%$-ával rendelkezett (Degryse - Nguyen, 2004).

Hazánkban a GDP növekedésével párhuzamosan emelkedik a kereslet az egyes banki szolgáltatások iránt. Ezzel kapcsolatosan nemzetközi összehasonlításban két mutatót érdemes megvizsgálni. Egyrészt a bankszektor GDP-hez való hozzájárulását, másrészt az úgynevezett transzmissziós hányadot. Spanyolországban $5,7 \%$, Portugáliában $5,45 \%$, míg a Luxemburgban 13,2\% a bankszektor GDP-hez való hozzájárulása. Magyarországon a teljes pénzügyi szektor - tehát nem csak a bankszektor - 4,5\%-kal járul hozzá a GDP-hez. A pénzügyi szolgáltatások teljes körének GDP-hez mért aránya Nyugat-Európában 8-12\% körül ingadozik (Lipták, 2001). A másik fontos mutató a transzmissziós hányad, ami a magyar bankrendszer által lebonyolított pénzügyi közvetítés súlyát jelenti. A bankszektor mérlegfőösszegének és a GDP-nek a hányadosa az elmúlt öt évben 60-70\% körül ingadozott, ami a 
bankrendszer csekélységére utal. Ez az arány a gazdaságilag legfejlettebb országokban 200-250\% körüli (B. Varga, 2001/a).

A bankok közvetítő szerepe ugyanakkor a hitelállomány alapján számítva folyamatosan nő, a hitel/ GDP mutató az 1998-as 25,8\%-ról 2002 végére 38,5\%-ra, 2003 végére pedig már 43,7\%-ra emelkedett. A tendencia ugyan pozitív, de az arány nemzetközi összehasonlításban még mindig alacsony, az Unió tagállamaiban a fenti arány 100\% körüli (Éves Jelentés..., 2004). Az elmaradottságot különösen jól mutatja a lakossági eladósodottság számos mutatószáma. Például a jelzálogkölcsönökkel együtt számított lakossági hitelezés Magyarországon 2003 végén a GDP körülbelül $10 \%$-a, szemben az uniós $50 \%$-kal (Nagy, 2003). Hasonlóan ehhez még mindig alacsony Magyarországon a lakáshitelek banki eszközökben mért aránya is. Az Európai Unió bankrendszerében a lakáshitelek aránya a banki eszközökben átlagosan 15\%-ot tesz ki, ez Magyarországon 2003 végére bár jelentősen megugrott, de még mindig csak $10 \%$ körüli (Éves Jelentés..., 2004). A növekvő bérkiáramlással együtt járó lakossági hitelállomány növekedése fogyasztási és autóvásárláshoz igénybe vett hitelek, lakáshitelek - mindenesetre a jövőben is valószínűsíthető. Ehhez hasonlóan prognosztizálható a kis- és középvállalkozások hitelezésének felfutása is. Nemzetközi összehasonlításban nagyon alacsony a vállalati hitelek állománya is mind a vállalatok forrásai között, mind a banki mérlegszerkezeten belül. Alacsony az éven túli kihelyezések aránya is, az Unió bankjainak eszközszerkezetében ez döntően kétharmados többséget jelent, Magyarországon pedig alig haladja meg az 50\%-ot (Lipták, 2001). A számok tükrében megállapítható, van még hova fejlődnie a bankszektornak. Ezt jelzi a bankszámlák alacsony egy főre jutó állománya - a magyar lakosság közel felének van bankszámlája, szemben a nyugat-európai fejenkénti két bankszámlával.

Bár elméletileg a bankszféra bármely szereplője sikeresen megállhatja a helyét a versenyben, valószínűleg a nagybankoknak több tartalékuk, és így több esélyük van rá. A kisbankok egy szűk piaci szegmensben, adott esetben valamely pénzügyi konglomerátumhoz csatlakozva lehetnek inkább sikeresek. A középbankok alapvetően stratégiai válaszút előtt állnak. Vagy sikeresen felküzdik magukat agresszív piacszerzési politikájuk, ${ }^{9}$ vagy potenciális felvásárlások és fúziók révén a nagybankok sorába, vagy lecsúsznak a kisbankok körébe, ahol vagy nyereségük megőrzése érdekében szakosodnak egy adott piaci résre, ha még találnak maguknak ilyet, vagy felvásárlás tárgyává válnak. ${ }^{10}$

$\mathrm{Az}$ említett, feltehetően igen lassú koncentrációs folyamatok eredményeképp a bankszektor kettős struktúrája valószínűsíthető. Egyrészt lesznek a tevékenységükben mind a nemzetközi, mind a hazai piacon eredményesen jelenlévő nagybankok, mint amilyennek most a Kereskedelmi és Hitelbank, a Magyar Külkereskedelmi Bank, a CIB Bank vagy a középkelet-európai régióban sikeresen tevékenykedő OTP tekinthető. ${ }^{11}$ Hosszú távon a korábbiakban elemzett fúziós lépéseknek és a kivonulásoknak köszönhetően körülbelül tíz általános szolgáltatásokat nyújtó nagybank talpon maradása prognosztizálható. A hazai bankok vezető munkatársainak körében gyakorlatilag már 1999-ben teljesen elfogadott volt az a nézet, hogy a piacot kis számú, teljes szolgáltatást nyújtó nagybank fogja uralni (Szabadhegy et al., 2000). A másik oldalon, a nagybankok mellett fontos szerepet fognak játszani a hazai piacra szakosodott, közvetlenül az adott régióra koncentráló, speciális hitelintézetek, amelyek mindenképp jelen lesznek, akár a jelenlegi jogi formában, akár egy pénzügyi konglomerátum részeként.

\section{Felhasznált irodalom}

Ahogy a Moody's... (2000): Ahogy a Moody's látja. http://www. cegnet.hu/gazdert/2000/52/cikk5.html. 2003. január 2. 21 ó. $35 \mathrm{p}$.

A Fundamenta-Lakáskassza... (2004): A Fundamenta-Lakáskassza Lakás-takarékpénztár Rt. bemutatása. http://www. fundamenta.hu/ceg_bemutatas.php?mp2\&am2. 2004. december 30.11 ó. 53 p.

B. Horváth Lilla (2003): A Bank of China Magyarországon. http://www.raba.hu/file/Kina_varja_a_magyar_termekeket _es_vallalkozokat_vg.htm. 2003. október 28.16 ó. 40 p.

B. Varga Judit (2001/a): Verseny a pénzpiacon. http:// www.cegnet.hu/gazdert/2001/26/m01261.htm. 2003. január 10. 10 ó. 19 p.

B. Varga Judit (2001/b): Bankvilág Magyarországon, Kon szolidálódó piac, dráguló díjakkal. http://www.cegnet.hu/ cv/0107/cv166_171.htm. 2003. január 16. 18 ó. 30 p.

Bankok és szakosított... (2001): Bankok és szakosított hitelintézetek toplistája 2000. Figyelő Top 200, http://www. fn.hu/cikk.php?layout=nocol $\&$ cid=47192\&id=44\#top. 2002. december 15.18 óra $35 \mathrm{p}$.

Bankok és szakosított... (2002): Bankok és szakosított hitelintézetek toplistája 2001. Figyelő Top 200, http://www. fn.hu/cikk.php?layout=nocol\&cid=47338\&id=44\#top. 2002. december 15.18 ó. 48 p.

Bankok, Rekorderek...(2004): Bankok, Rekorderek. Figyelố Top 200. Figyelő Különszám. 2004. október

Degryse, Hans - Nguyen, Grégory (2004): Interbank Exposures: An Empirical Examination of Systemic Risk in the Belgian 
Banking System. National Bank of Belgium Working Paper, No. 43.

Economies of scale ... (2002): Economies of scale. http:// econserv2.bess.tcd.ie/amtthews /EurEcon/Lectures/Lecture06/ tsld006.htm, 2002. április 13.12 ó. 25 p.

Éves Jelentés... (2004): Éves Jelentés 2003. Pénzügyi Szervezetek Állami Felügyelete, http://www.pszaf.hu/magyar/frm2.asp? left=dokutar.htm\&cont=dokutar/index.htm. 2004. december 29. 21 ó. 30 p.

Gál Péter (2000): A bankszféra átrendeződése a világgazdaságban, Nagyra nőnek. http://www.arcanum.hu/figyelo/lpext.dll/ figyelo/ $21 \mathrm{ef0} / 255 \mathrm{~b} / 26 \mathrm{bf} / 26 \mathrm{c} 0.2004$. december 29.19 ó. 44 p.

I-1867/2002. számú határozat......(2002): I-1867/2002. számú határozat a Société Générale Hungária Bank Rt. pénzügyi vállalkozássá történő átalakításának engedélyezéséről. http:// www.pszaf.hu/hatarozatok/200208/20020813/I-18672002.htm. 2003.január 10. 16 ó. 49 p.

I-929/2002. számú határozat...(2002): I-929/2002. számú határozat a Rabobank Hungária Kereskedelmi Bank Rt pénzügyi vállalkozássá való átalakításának engedélyezéséről. http:// www.pszaf.hu/hatarozatok/200206/20020604/I-929.htm 2003. január 10. 16 ó. 19 p.

Kopányi Mihály (1999): Mikroökonómia. Múszaki Könyvkiadó. Budapest

Lipták Zoltán (2001): A magyar bankrendszer középtávú fejlődési kilátásai stratégiai megközelítésben. Bankszemle, XLV. évf. 6. szám

Merkantil Bank... (2004): Merkantil Bank az OTP bankcsoport tagja. www.merkantil.hu. 2004.december 29. 19 ó. 35 p.

MKB, Bemutatkozunk (2004): MKB, Bemutatkozunk, A bank története. http://www.mkb.hu/red_bemutatkozunk/tortenet/ tortenet.mkb. 2004.december 29. 18 ó. 41 p.

Mouyneux, Philip -Altunbas, Yener - Gardener, Edward (1997): Efficiency in European Banking. Chishester, John Wiley \& Sons. Chichester

Nagy Gábor (2003): Keleti gyűjtés, A Moody's a magyar bankszektorról. HVG melléklet a bankokról. 2003. augusztus 16 .

Nomura Securities... (2004): Nomura Securities Hungary Ltd. http://www.nomura.com/hungary-eng/. 2004.december 29. 20 ó. 32 p.

Novák Tamás - Wisniewski Anna (1999): Formálódó bankrendszerek, Tôkeerôs versenytársak térségünkben. http://www cegnet.hu/cv/9911/cv102_114.htm. 2003.január 10. 9 ó. 46 p.

Piaci szereplők...(2004): Piaci szereplők, Nyilvántartások, Fióktelepek - határon átnyúló szolgáltatók, Pénzpiac. http:// www.pszaf.hu/magyar/frm2.asp?left=piac.htm\&cont=piac/ind ex.htm. 2004. december 29. 20 ó. 2 p.

Sopron Bank... (2004): Sopron Bark Rt. http://www. sopronbank.hu/html/hun/bemut.html. 2004.december 29. 20 ó. $18 \mathrm{p}$.

Special Features...(2001): Special Features on Banking. Eurostat. Brussels

Szabadhegy Péter - Gyôri Csaba - Baráth Mónika (2000): Középeurópai bankvezetők jövőképe. Bankszemle, XLI. évf. 4-5. sz.

Tompa Tamás - Lemák Gábor - Sulok Zoltán (2001): Fúziók és felvásárlások, A vállalategyesítések Magyarországon is folytatódnak. http://www.cegnet.hu/cv/0106/cv094_099.htm. 2003.január 10. 22 ó. 33 p.

Top 100 Central ...(2003): Top 100 Central Europeans, Annual Ranking. http://thebanker.inta.net.uk/rankings/top_100_central_europe/index.shtml. 2003. november 5. 10 ó.17 p.

Várhegyi Éva (2002): Bankvilág Magyarországon. Helikon Kiadó. Budapest
Zöld utat... (2003): Zöld utat kapott az Erste Bank a Postabank megvásárlásához. http://www.erstebank.hu/content/Magyar/ c741.html. 2003. október 29. 15 ó. 55 p.

1996. évi CXII... (1996): 1996. évi CXII. a hitelintézetekről és a pénzügyi vállalkozásokról szóló törvény. http://www. complex.hu/kzldat/t9600112.htm/t9600112.htm. 2004.noveber 10.9 ó. 30 p.

\section{Lábjegyzetek}

${ }^{1}$ Elméletileg itt számos bank esetét meg lehetne megemlíteni. Vegyük elốször az IBUSZ Bankot. A bank a világútlevél bevezetésekor a devizaszámla-vezetés piacán jelentős sikereket ért el, és megvetette a lábát a lakossági piac egyéb területein is. Vélhetốen az 1991-ben alapított bank vảgy egyszerúen nem volt képes kiaknázni lehetőségeit, vagy az adottságai eleve nem tették lehetôvé a gazdaságos üzemméret kialakítását, így a pénzintézetet 1999-ben magába olvasztotta a Kereskedelmi és Hitelbank (B. Varga Judit, 2001/b). De a fúzió fenti kategóriájába sorolhatnánk a tôkkeerôs, de ügyfélszegény Pénzintézeti Központ Banknak és a tőkehiányos, de ügyfelekben bővelkedô Polgári Banknak - az állami vagyonkezelő segítségével megvalósuló - Polgári Kereskedelmi Bankká történô integrálását, majd a Polgári Kereskedelmi Bank Postabanknak történő eladását, mely eredményeképp a kezdeti három bankból egy bank lett. Végül a bukott Agrobank 1996-os Mezóbankba történő beolvasztását és a Corvinbank 1998-as Konzumbankba történô integrálását érdemes megemlíteni. Valamennyi fenti ügylet mögött azonban az érdekek bonyolult hálója és a politika húzódik meg. A fenti, sokszor kényszer szülte fúziók hiteles leírását és a hozzá kapcsolódó magyarországi bankprivatizáció korántsem zökkenőmentes folyamatáról bővebben lásd Várhegyi Éva: Bankvilág Magyarországon című könyvét (Várhegyi, 2002). Tanulmányomban az ABN Amro és a Kereskedelmi és Hitelbank fúzióját leszámítva a lábjegyzetben említett fúziók nem kapnak kiemelt szerepet, ugyanis sokkal inkább a múlt rendszer örökségének és a politika ármányainak tudhatók be, mintsem piaci érdekek által vezéreltnek.

${ }^{2}$ A források megszerzéséért folytatott versenyt jól mutatja az is, hogy az USA-ban a bankok részesedése egyre inkább csökken a pénzügyi szektor aktíváiban (Gál, 2000).

3 A Banker 100 Kelet-Európa legnagyobb bankjait tartalmazó rangsorában az OTP a 15., a K\&H a 19., a Magyar Külkereskedelmi Bank a 22., míg a CIB a 24. (Top 100 Central Europeans..., 2003).

${ }^{4}$ A Sopron Bank Részvénytársaságot a Bank Burgenland alapította, amely vezetô regionális banki szerepet játszik Burgenland Szövetségi Tartományban. A Sopron Bank különös hangsúlyt helyez a régió határon átnyúló vállalkozásainak testre szabott finanszírozására és az ügyfelek Európai Unión belüli határokon túlnyúló gazdasági mozgásterének bővítésére, támogatására (Sopron Bank..., 2004). A Bank of China elsősorban a Magyarországon élő mintegy harmincezer kínai állampolgárnak és a kétezernyi itt bejegyzett kínai vállalkozásnak kíván szolgáltatásokat nyújtani. A kínai banki érdekeltség célja az intenzív magyar-kínai kereskedelmi kapcsolatokban a pénzügyi háttérintézmény szerepének betöltése, ami egyaránt jelenti a kínai kereskedők eredményesebb üzleti tevékenységének támogatását, és a kínai vállalatok magyarországi befektetéseinek elősegítését (B. Horváth, 2003).

5 A hitelintézetek egyesülésével kapcsolatosan, a betétesek védelmének érdekében az 1996. évi CXII. a hitelintézetekrôl és a pénzügyi vállalkozásokról szóló törvény is tartalmaz rendelkezéseket. A törvény $101 \S$-ában található ide vonatkozó részeit a 2000. évi CXXIV. törvény 71. § (2)-a állapította meg (1996. évi CXII..., 1996). Jól mutatja ez is, hogy a törvényalkotók is felkészültek egy-egy újabb fúzióra. 
${ }^{6}$ A túlbankosodás persze relatív. Míg a bankok számát tekintve a magyar piac túlbankosodottnak tekinthetô, addig a fiókok és a pénzkiadó automaták számát alapul véve nem mondható el ugyanez.

${ }^{7}$ A Nomura Bank 1998-ban befektetési társasággá alakult át (Nomura Securities..., 2004). A Nomura Bankhoz hasonló cipőben járt a K\&H-hoz tartozó, portfóliótisztításban, követelések behajtásában és értékesítésében, valamint gazdálkodó szervezetek reorganizációjában jártas Kvantum Investment Bank, amely 1999 során pénzügyi vállalkozássá alakult át. De ide sorolhatnánk az élelmiszeripar és mezôgazdaság finanszírozására szakosodott Rabobankot és a hatékony mủködéshez elégtelen ügyfélszámmal rendelkezô Société Générale Hungária Bankot is. Az előbbi 2002 májusában, míg az utóbbi 2002 júliusában ugyanis a Felügyelettől megkapta az engedélyt, hogy pénzügyi vállalkozássá alakuljon át (I-929/2002. számú határozat..., 2002; I-1867/2002. számú határozat..., 2002). Szintén 2002-ben hagyta ott a bankszektort és eleget téve a törvényi előirásoknak szakosított hitelintézetből pénzügyi vállalkozássá alakult át a GMAC nevet viselő, autófinanszírozásra szakosodott Opelbank.
8 Amellett, hogy a fúzió jelentős egyszeri veszteségekkel jár - informatikai rendszerek harmonizálása, két vállalati kultúra közötti összhang megteremtése, létszámleépítések miatti végkielégítési kötelezettségek rendezése, fiókok bezárásra - az integráció vég nélkül nem folytatható, a bankméret növekedése és a gazdaságosság alakulása közötti kapcsolat fordítottá válhat. Egy bizonyos méret felett a bankok további növekedése nem feltétlenül jár globális költségelőnyökkel, hatékonyságnövekedéssel és a fajlagos eredményességet sem javítja, ahogy történt ez számos esetben Ausztriában vagy Németországban (Tompa et al., 2001).

${ }^{9}$ Ahogy annak idején a Volksbank átkerült a kisbankok közül a középbankok közé.

10 A szűk piaci résre szakosodott bankok közül a Porsche Bank, a Daewoo Bank, illetve a Magyar Cetelem az iparági átlag felett tudnak teljesíteni mind a tôkemegtérülés, mind a mérlegfôösszeg növekedésének vonatkozásában (Papp, 2000).

11 Értelmetlen lenne gyorsan változó világunkban jóslatokba bocsátkozni, hogy mely bankok maradnak talpon, főként, hogy sok minden nem is az itthoni színfalak mögött dől el, hanem a külföldi bankok globális stratégiájának megalkotása során, aminek a lecsapódását a magyar bankszektor csupán elszenvedi.

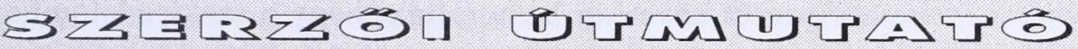

A Vezetéstudomány a Budapesti Corvinus Egyetem Gazdálkodástudományi Kar Budapesti Vezetőképző Központjának havi folyóirata. A lapban a vezetési, és tudományterületekhez kapcsolódó témakörök elméleti és gyakorlati kérdéseit elemző és vizsgáló írások jelennek meg. A szerkesztőség (robert.becsky@uni-corvinus.hu) elektronikus formában kéri az írásokat. A cikkeket elektronikus levélben vagy mágneslemezen (MS Word fájl formátumban) lehet a szerkesztőséghez eljuttatni.

A lap tudományos folyóirat, ezért szövegközi forráshivatkozások és ezek jegyzéke nélküli írásokat nem jelentet meg. A Vezetéstudományban megjelentetni szándékozott kéziratok szerzőitôl az alábbi követelmények figyelembevételét kérjük:

A cikkek szokásos terjedelme a hivatkozásokkal, ábrákkal és táblázatokkal együtt 20-24 oldal, 1,5-es sortávolsággal (12-es betűméret, Times New Roman betűtípus). A cikkek első oldalának alján tüntessék fel a szerző foglalkozását, munkahelyét beosztását, és elektronikus levelezési címét, a tanulmány elkészítésével kapcsolatos információkat és az esetleges köszönetnyivánításokat.

A kézirathoz csatolandó egy magyar nyelvű és lehetőség szerint egy angol nyelvú rövid összefoglaló (200 szót nem meghaladó terjedelemben), valamint a cikk fő témaköreit megnevező kulcsszavak jegyzéke.

Kiemeléshez félkövér és dőlt betű használható, aláhúzás nem. Jegyzeteket lehetőleg ne használjanak, amennyiben azok feltétlenül szükségesek, szövegvégi jegyzetként adják meg.

A táblázatoknak és ábráknak legyen sorszáma és címe, valamint - átvett forrás esetén - pontos hivatkozása. Az ábrákat és a táblázatokat a kézirat végén, külön oldalakon, sorszámmal és címmel ellátva kérjük csatolni, helyüket a szövegben egyértelműen jelölve (pl. „Kérem az 1. táblázatot kb. itt elhelyezni!)"”

A szövegközi bibliográfiai hivatkozásokat zárójelben, a vezetéknév és az évszám feltüntetésével kérjük jelölni: pl. (Veress, 1999); szó szerinti, idézőjeles hivatkozás esetén kiegészítve az oldal(ak) számával (pl. Prahalad-Hamel, 1990: 85). Amennyiben egy hivatkozott szerzőnek több bibliográfiai tétele van ugyanazon évben, ezeket 1999a, 1999b stb. módon kell megkülönböztetni. A felhasznált források cikk végén elhelyezett jegyzékét ábécérendben kérjük, a következő formában:

Szerző (évszám): Cím, kiadás helye: kiadó, illetve forrás.

1) példa (könyv): Porter, M. E. (1980): Competitive Strategy; New York: The Free Press.

2) példa (folyóirat-cikk): Prahalad, C. K. és G. Hamel (1990): The Core Competence of the Corporation; Harvard Business Review, május-június, 79-91.

A formai követelmények fentiekben érvényesített, ún. „Harvard” rendszeréről (más néven „szerző/év” vagy „név/dátum” hivatkozási módszerről) részletes tájékoztatást nyújtanak a Vezetéstudomány WEB-címén (www.bsm.hu; ,,Vezetéstudomány/Szerzőinknek" menüpont) megadott források.

Havi folyóirat lévén és a megjelenés átfutási idejének csökkentése érdekében a Vezetéstudomány kefelevonatot nem küld, elfogadás elôtt azonban a szerzőknek egyeztetés céljából elküldi a cikk szerkesztett változatát.

A szerkesztőség 